\title{
Detection and Transfer of Extended Spectrum Beta Lactamase Enzymes from Untreated Hospital Waste Water
}

\author{
Olivia Sochi Egbule \\ Department of Microbiology, Delta State University, Abraka, Nigeria \\ Email: oliviaegbule@gmail.com
}

Received 13 May 2016; accepted 24 June 2016; published 27 June 2016

Copyright (C) 2016 by author and Scientific Research Publishing Inc.

This work is licensed under the Creative Commons Attribution International License (CC BY).

http://creativecommons.org/licenses/by/4.0/

(c) (i) Open Access

\begin{abstract}
Untreated Hospital wastewater piped into septic tanks contributes to the spread of antibiotic resistance in developing countries. This study was conducted to determine the resistant profile, and Extended Spectrum Beta-Lactamases (ESBLs) production in isolates from hospital waste water, of 2 hospitals in Delta State, Nigeria. A total of 147 organisms were isolated from 32 waste water samples. One hundred and twenty three isolates were Gram negative and 24 were Gram positive. Escherichia coli was the most prevalent in the two locations. Antimicrobial susceptibility by standard disk diffusion method was performed. All isolates were resistant to 4 or more antimicrobial agents. Out of the 123 Gram negative Bacteria, 33 were pan drug resistant and were selected for plasmid curing, DNA extraction and phenotypic detection of ESBL. Transfer of resistant by broth mating technique was performed. Plasmid curing and extraction result indicated that isolates carried resistance on the plasmid and harboured similar multiple high molecular weight plasmids of $23.13 \mathrm{~kb}$ and $9.4 \mathrm{~kb}$. ESBL production was detected in $15.15 \%$. Transfer of resistant genes between ESBL producing and non-ESBL producing isolates was observed. Incidence of ESBL in untreated hospital waste water has public health implications. Therefore establishment of treatment plants in our hospital is paramount in achieving sustainable health.
\end{abstract}

\section{Keywords}

Waste Water, Plasmids, ESBL, Escherichia coli

\section{Introduction}

Hospital effluents from operation theatres, laboratories and infected patients contribute significantly to the pol-

How to cite this paper: Egbule, O.S. (2016) Detection and Transfer of Extended Spectrum Beta Lactamase Enzymes from Untreated Hospital Waste Water. Advances in Microbiology, 6, 512-520. http://dx.doi.org/10.4236/aim.2016.67051 
lution of natural environment. Mismanagement of hospital effluents has largely been over looked. These effluents are loaded not only with pathogenic microorganisms but also with pharmaceuticals and toxic chemical substances, some of which are recalcitrant [1] [2]. Most antibiotics administered to patients are partially metabolized, as such are found in varying concentrations in hospital wastes water. Sewage treatment reduces the number of bacteria in wastewater [3]. In most developing countries, hospitals do not have sewage treatment plants treating effluents. The effluents are piped into septic tanks without pre-treatment. This is of major risk to public health as these septic tanks are liable to leakage, collapse and there are clear possibilities for microorganisms to sip into ground water. The wastewater may also enter into surface water bodies and cause pollution. [4] [5] have attributed the deterioration in water quality to pollutants entering surface and ground water sources.

Patients care givers and laboratory personnel play a lot of role in polluting hospital environment with effluents, as they accidentally and/or deliberately introduce harmful liquid wastes into hospital environment. Transfer of resistance genes as well as the already resistant bacteria themselves is facilitated if antibiotics are present in sub-therapeutic concentration and over a long period [6]. As antibiotics are continuously released into the environment, a niche of resistant bacteria is created. The development of resistance by persistent exposure of bacteria to such sub-therapeutic antimicrobial concentration favors transfer.

In normal circumstances as is the case in most developed countries of the world, health-care sewages are pretreated before discharge into municipal sewers. Several studies evaluating the microbiological content of hospital and household wastes have found that hospital wastes contain pathogenic bacteria that could be harmful to humans than there are in household wastes [7]-[9]. It is paramount therefore that in the establishment of sewage treatment plants, in developing countries yet to establish municipal sewers, hospital sewage should undergo a pretreatment.

The present study was carried out to determine the prevalence of resistant pathogens in effluents and to stress the need for sewage treatment plants.

\section{Materials and Methods}

\subsection{Study Area}

Hospital waste water samples were collected from two hospitals in Delta State; Delta State University (DELSU) health centre Abraka and Federal Medical Centre (FMC) Asaba.

\subsection{Sample Collection}

Waste water in the hospitals sampled are usually not treated before they are piped into septic tanks. The waste water samples used in this study were therefore collected before they were poured into sinks or carelessly thrown away outside the hospital environment. Samples were collected from laboratories, theatres and wards at 4 weeks interval over a period of 4 months.

\subsection{Sample Processing, Isolation and Identification}

Samples were transported to the laboratory in Ice Park and processed within 2 hours of collection. Each sample was inoculated on Macconkey agar, Blood agar and Pseudomonas agar. Incubation followed at $37^{\circ} \mathrm{C}$ for 24 -hrs. Representative pure colonies were picked based on morphology. The isolated colonies were identified biochemically following standard methods.

\subsection{Antimicrobial Susceptibility}

Antimicrobial Susceptibility tests were carried out on isolates by standard disk diffusion method on MuellerHinton Agar (MHA) agar according to [10]. The antibiotics used were Nitrofurantoin (300 $\mu$ g), Ciprofloxacin (5 $\mu \mathrm{g})$, Ceftazidine $(30 \mu \mathrm{g})$, Cefuroxime $(5 \mu \mathrm{g})$, Gentamicin $(10 \mu \mathrm{g})$, Ofloxacin $(5 \mu \mathrm{g})$. Amoxicillin-Clavulanic acid (30 $\mu \mathrm{g})$, Cefixime (5 $\mu \mathrm{g})$, Cefotaxime (30 $\mu \mathrm{g})$ (Oxoid UK).

The bacteria inoculum was prepared by suspending isolates in $5 \mathrm{ml}$ of sterile nutrient broth and adjusting the turbidity to that of 0.5 McFarland standard. Aliquots from each suspension were spread plated on MHA agar. The antibiotic discs were then placed on the surface of the plate using sterile forceps.

Plates were incubated aerobically at $37^{\circ} \mathrm{C}$ for $24 \mathrm{hrs}$. The zones of inhibition were measured and recorded as 
resistant or sensitive based on [10].

\subsection{Plasmid Curing and DNA Extraction}

Plasmid curing was carried out using sodium dodecyl sulfate (SDS) as the curing agent [11]. Bacteria DNA was extracted using Qiagen extraction kit (Qiagen, UK), following manufacturer's instructions and by alkaline extraction procedures of [12].

\subsection{ESBL Detection by Double Disc Synergy Test (DDST)}

ESBL production was detected phenotypically by the Double Disc Synergy Test (DDST) according to [13]. Briefly, the isolates were inoculated in nutrient broth at $37^{\circ} \mathrm{C}$ for $5 \mathrm{hrs}$. The turbidity was adjusted to $0.5 \mathrm{McFar}-$ land standards using normal saline solution. A lawn culture of the isolates was made on the surface of MuellerHinton agar plates using sterile cotton swab. An Augmentin disc was placed at the centre of the plate. A Cefotaxime $(30 \mu \mathrm{g})$ and Ceftazidine $(30 \mu \mathrm{g})$ disc were placed $15 \mathrm{~mm}$ apart on both side of the centrally placed Augmentin disc. The plates were incubated at $37^{\circ} \mathrm{C}$ for 24 hrs. Increase in the zone of inhibition of either/or both Ceftazidime and Cefotaxime towards the Augmentin disc was interpreted as positive.

\subsection{Conjugation Experiment}

Conjugation by broth mating technique as described by [14] and the method adopted by [15] was carried out using 5 ESBLs producing isolates as donors (3 Escherichia coli, 2 Pseudomonas aeruginosa and 1 Klebsiella pneumonia) and four non-ESBL producers as recipients (2 Pseudomonas aeruginosa and 2 Escherichia coli).

Briefly, the recipient and donor strains were grown in $5 \mathrm{ml}$ of $\mathrm{LB}$ broth, incubated at $37^{\circ} \mathrm{C}$ for 24 hrs. Overnight culture of the bacteria was diluted in LB broth and cell density adjusted to $1.5 \times 10^{8}$ cells/ml. The cultures of donor and recipient were mixed at a ratio of $1: 2$ (donor:recipient) in $1 \mathrm{ml}$ of LB broth, and incubated at $37^{\circ} \mathrm{C}$ for 24 hrs. To recover ESBL producing isolates; samples of the mixtures were inoculated on MacConkey (Hi media, India), and incubated at $37^{\circ} \mathrm{C}$ for 24 hrs. The mixed colonies of the transconjugants were subjected to biochemical analysis following standard procedures and ESBLs screening by phenotypic test. A separate culture of donor and recipient diluted in phosphate buffer saline with a dilution of $10^{-3}$ and $10^{-5}$ plated on MacConkey agar were used as control.

\section{Result}

A total of 32 waste water samples (16 from each centre) were obtained from Delsu Health Center (DHC), Abraka and Federal Medical Centre (FMC), Asaba. The samples were processed for the presence of drug resistance bacteria pathogens, $\beta$-lactamase production and the ability to transfer resistance markers. A total of 147 isolates were obtained; 67 isolates were obtained from DHC, Abraka (Table 1) while 80 isolates were from

Table 1. Number of isolates from Delsu Health Centre (DHC) waste water.

\begin{tabular}{cc}
\hline Isolates & No of isolate (\%) \\
\hline Escherichia coli & $20(29.85)$ \\
Pseudomonas aeruginosa & $06(8.96)$ \\
Klebsiella pneumonia & $14(20.90)$ \\
Aeromonas sp. & $05(7.46)$ \\
Salmonella sp. & $08(11.94)$ \\
Proteus mirabilis & $10(14.93)$ \\
Staphylococcus aureus & $04(5.97)$ \\
Total & 67
\end{tabular}


FMC, Asaba (Table 2). One hundred and twenty three Gram negative and 24 Gram positive organisms were isolated. E. coli was the most frequently isolated organism from both DHC, Abraka (29.85\%) and FMC, Asaba (25.00\%). Other gram negative organism isolated, were Pseudomonas aeruginosa, Klebsiella pneumoniae, Aeromonas sp., Salmonella sp., Proteus mirabilis, Shigella dysenteriae. The Gram positive organism isolated include Bacillus subtilis and Staphylococcus aureus (Table 1 and Table 2).

All the isolates were multi drug resistant; being resistant to 4 or more antibiotics. All the isolates in these study were resistant to one or more $\beta$-lactam antibiotic used. The Gram negative isolates obtained from DHC Abraka, though showed high levels of resistance (Table 3), however higher levels of resistance were observed in FMC, where all Pseudomonas aeruginosa and Klebsiella pneumoniae were resistant to all antibiotics tested (Table 4). Similarly all Gram positive organisms isolated were resistant to all antibiotics tested (Table 5). Of the 123 gram negative organisms isolated, 33 (26.83\%) were pan drug resistant (resistance to all antimicrobial agent tested). These pan drug resistant gram negative isolates were selected for further studies. Result of plasmid curing indicated that the isolates harbored one or more resistance on the plasmid (Table 6 \& Table 7). A most striking observation on carriage of resistance on the plasmid was with Pseudomonas aeruginosa. Pseudomonas aeruginosa harbored the highest number of antibiotics on the plasmid as indicated by the number of antibiotics lost after curing (Table 7). Out of the nine pan drug resistant isolates selected for plasmid extraction, 7 harboured multiple similar high molecular weight plasmid of $23.13 \mathrm{~kb}$ and $9.4 \mathrm{~kb}$ (Figure 1).

The result of ESBLs production by DDST indicated that 3 E. coli, 1 Klebsiella pneumoniae and 2 Pseudomonas aeruginosa were positive. It was also observed that all the 5 ESBL producing isolates were pan drug resistance.

Transfer of resistant genes between ESBL producing and non-ESBL producing isolates was observed in this study. Result is shown in Table 8.

Table 2. Number of isolates from Federal Medical Center (FMC) waste water.

\begin{tabular}{cc}
\hline Isolates & No of isolates (5) \\
\hline Escherichia coli & $20(25.00)$ \\
Pseudomonas aeruginosa & $10(12.50)$ \\
Klebsiella pneumonia & $10(12.50)$ \\
Aeromonas sp. & $06(7.50)$ \\
Shigella dysenteriae & $08(10.00)$ \\
Salmonella sp. & $06(7.50)$ \\
Bacillus subtilis & $12(15.00)$ \\
Staphylococcus aureus & $08(10.00)$ \\
Total & 80
\end{tabular}

Table 3. Percentage Antimicrobial susceptibility test of waste water isolates from DHC, Abraka.

\begin{tabular}{ccccccccccc}
\hline Isolates & CAZ & CXM & CRM & CFT & OFL & GEN & CPR & NIT & AUG \\
\hline Escherichia coli & 90.00 & 80.00 & 80.00 & 90.00 & 90.00 & 80.00 & 80.00 & 50.00 & 70.00 \\
P. aeuroginosa & 85.7 & 85.71 & 85.71 & 100.00 & 100.00 & 71.43 & 71.43 & 71.43 & 57.14 \\
K. pneumoniae & 66.67 & 100.00 & 66.67 & 66.67 & 66.67 & 100.00 & 6.667 & 66.67 & 100.00 \\
Aeromonas sp. & 80.00 & 80.00 & 80.00 & 80.00 & 40.00 & 80.00 & 40.00 & 20.00 & 100.00 \\
Salmonella sp. & 100.00 & 100.00 & 100.00 & 100.00 & 87.50 & 100.00 & 87.50 & 87.50 & 87.50 \\
Proteus mirabilis & 100.00 & 70.00 & 70.000 & 100.00 & 37.50 & 62.50 & 37.50 & 37.50 & 70.00 \\
\hline
\end{tabular}

CAZ = Ceftazidine; CXM = Cefixime; CRM = Cefuroxime CFT = Cefotaxime; OFL = Oflaxacin; GEN = Gentamycin; CPR = Ciprofloxacin; NIT = Nitrofloxacin; AUG = Augmentine. 
Table 4. Percentage Antimicrobial susceptibility test of waste water isolates obtained from FMC, Asaba.

\begin{tabular}{ccccccccccc}
\hline Isolates & CAZ & CXM & CRM & CFT & ÒFL & GEN & CPR & NIT & AUG \\
\hline P. aeuroginosa & 100.00 & 100.00 & 100.00 & 100.00 & 100.00 & 100.00 & 100.00 & 100.00 & 100.00 \\
K. pneumoniae & 100.00 & 100.00 & 100.00 & 100.00 & 100.00 & 100.00 & 100.00 & 100.00 & 100.00 \\
S. dysenteriae & 100.00 & 100.00 & 100.00 & 100.00 & 75.00 & 75.00 & 75.00 & 62.50 & 100.00 \\
Aeromonas sp. & 100.00 & 100.00 & 100.00 & 100.00 & 100.00 & 100.00 & 100.00 & 50.00 & 100.00 \\
Escherichia coli & 100.00 & 100.00 & 100.00 & 100.00 & 100.00 & 100.00 & 100.00 & 66.60 & 100.00 \\
Salmonella sp. & 100.00 & 100.00 & 100.00 & 100.00 & 66.60 & 1100.00 & 66.60 & 100.00 & 100.00 \\
Proteus mirabilis & 100.00 & 100.00 & 100.00 & 60.00 & 100.00 & 100.00 & 50.00 & 50.00 & 100.00 \\
\hline
\end{tabular}

CAZ = Ceftazidine; CXM = Cefixime; CRM = Cefuroxime CFT = Cefotaxime; OFL = Oflaxacin; GEN = Gentamycin; CPR = Ciprofloxacin; NIT = Nitrofloxacin; AUG = Augmentine.

Table 5. Percentage Antibiotics resistance Profile of gram positive bacterial isolates in hospital effluent.

\begin{tabular}{|c|c|c|c|c|c|c|c|c|c|}
\hline & COT & CXC & ERY & CFT & GEN & AUG & STR & TET & CHL \\
\hline Staphylococcus (6) & 100.00 & 100.00 & 100.00 & 100.00 & 10.0 & 100 & 100 & 100 & 100 \\
\hline Bacillus sp. (4) & 100.00 & 100.00 & 100.00 & 100.00 & 100 & 100 & 100 & 100 & 100 \\
\hline
\end{tabular}

Key: COT Cloxacillin, CXC Cotrimoxazole, ERY Erythromycin, GEN Gentamycin, AUG Augumentin, TET Tetracyclin, STR Streptomycin, CHL Chloramphenicol.

Table 6. Plasmid curing of pan drug resistant isolates from waste water samples obtained from Delsu Health Centre.

\begin{tabular}{cccc}
\hline Isolates & Isolates code & $\begin{array}{c}\text { Number of } \\
\text { resistant carried }\end{array}$ & $\begin{array}{c}\text { Number of } \\
\text { resistance lost }\end{array}$ \\
\hline \multirow{2}{*}{ E. coli } & DH EC01 & 9 & 9 \\
& DH EC02 & 9 & 9 \\
& DH EC03 & 9 & 8 \\
Klebsiella & DH EC04 & 9 & 7 \\
\hline pneumonia & DH K01 & 9 & 5 \\
& DH K02 & 9 & 5 \\
& DH K03 & 9 & 9 \\
\hline
\end{tabular}

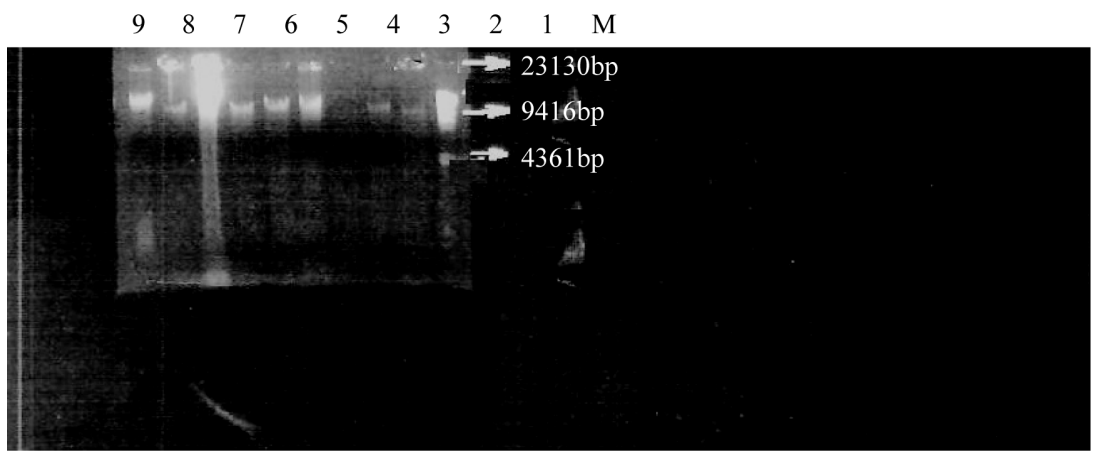

Figure 1. Plasmid DNA of isolates from untreated hospital waste water. 
Table 7. Plasmid curing of pan drug resistant isolates from waste water samples obtained from Federal Medical Center, Asaba.

\begin{tabular}{|c|c|c|c|}
\hline Isolates & $\begin{array}{l}\text { From FMC } \\
\text { Isolate Code }\end{array}$ & $\begin{array}{l}\text { Number of resistance } \\
\text { before curing }\end{array}$ & $\begin{array}{c}\text { Number of resistance } \\
\text { after curing }\end{array}$ \\
\hline \multirow{10}{*}{$\begin{array}{c}\text { Pseudomonas } \\
\text { aeruginosa }\end{array}$} & FMCPso1 & 9 & 9 \\
\hline & FMCPs0 2 & 9 & 9 \\
\hline & FMCPs03 & 9 & 8 \\
\hline & FMCPs04 & 9 & 8 \\
\hline & FMCPs05 & 9 & 7 \\
\hline & FMCPs06 & 9 & 8 \\
\hline & FMCPs07 & 9 & 7 \\
\hline & FMCPs08 & 9 & 6 \\
\hline & FMCPs09 & 9 & 6 \\
\hline & FMCPs10 & 9 & 6 \\
\hline \multirow{9}{*}{$\begin{array}{l}\text { Klebsiella } \\
\text { pneumonia }\end{array}$} & FMCKs01 & 9 & 1 \\
\hline & FMCKs02 & 9 & 5 \\
\hline & FMCKs03 & 9 & 5 \\
\hline & FMCKs04 & 9 & 5 \\
\hline & FMCKs05 & 9 & 5 \\
\hline & FMCKs06 & 9 & 6 \\
\hline & FMCKs07 & 9 & 8 \\
\hline & FMCKs08 & 9 & 8 \\
\hline & FMCKs09 & 9 & 7 \\
\hline \multirow{6}{*}{ E. coli } & FMCEs01 & 9 & 8 \\
\hline & FMCEs02 & 9 & 4 \\
\hline & FMCEs03 & 9 & 5 \\
\hline & FMCEs04 & 9 & 5 \\
\hline & FMCEs05 & 9 & 5 \\
\hline & FMCEs06 & 9 & 8 \\
\hline
\end{tabular}

Table 8. Transfer of resistance genes between ESBL and non-ESBL producing isolates.

\begin{tabular}{ccc}
\hline $\begin{array}{c}\text { Donor } \\
\text { (No. of donor isolate) }\end{array}$ & $\begin{array}{c}\text { Recipient } \\
\text { (No. of recipient isolate) }\end{array}$ & No. of Transconjugants \\
\hline E. coli (3) & P. aeruginosa (2) & 1 \\
Pseudomonas aeruginosa (2) & E. coli (2) & 1 \\
Klebsiella pneumonia (1) & P. aeruginosa (2)
\end{tabular}




\section{Discussion}

Health improvement and environmental protection are the two major challenges developing countries are faced with. There are lack of facilities such as sewage treatment plants in the hospitals. Most antimicrobial agents used to treat infections are only partially metabolized by patients. These antimicrobial agents are discharged into septic tanks in most developing countries or end up accidentally or deliberately in the environment. Resistant bacteria may be selected by antibiotic substances in hospital. There are clear possibilities that these partially-metabolized or resistant bacteria enter into surface or ground water [3] [16]. Most studies have evaluated the microbiological content of treated hospital waste water effluents [17] [18] and have found that these hospital waste effluent though undergo sewage treatment, they still contain bacteria with pathogenic potentials for humans and antibiotic resistant bacteria [17]. The hospital waste water in most developing countries like Nigeria are not treated, they are either deliberately/accidentally thrown away or are piped into septic tanks without treatment. Untreated hospital effluents, therefore contains concentrated forms of infections agents and antimicrobial resistant organisms which when released into the environment result in a myriad of infections. Provision of treatment plant per se may not be the only means of achieving a better quality of life in developing countries. Unlike developed countries, most developing countries are faced with illiterates as hospital cleaners or care givers, who are unaware of the health implication of disposing liquid wastes without treatment. There is need to invest in the training and educating of cleaners on the dangers associated with disposing untreated hospital effluents into the environment.

Most of the organisms isolated in this study are frequently found in hospitalised patients. E. coli was the most prevalent in the two hospitals sampled. Other gram negative organisms isolated include Klebsiella pneumoniae, Pseudomonas aeruginosa, Aeromonas sp., Salmonella sp., Shigella dysenteriae and Proteus mirabillis. The gram positive organisms were Bacillus subtilis and Staphylococcus aureus. The presence of opportunistic pathogens such as Klebsiella pneumoniae poses serious implications especially for the immunocompormised living in the community. The presence of isolates such as Aeromonas sp., Salmonella sp. and Shigella dysenteriae that are associated with gastroenteritis are of concern especially for young children.

Antimicrobial resistance has been recognized as a significant problem worldwide [19] both in developed and developing countries. All the isolates in this study were resistant to one or more $\beta$-lactam antibiotic used. This indicates that the organisms have been well exposed to these antibiotics and have developed resistance to them. The $\beta$-lactam antibiotics are one of the treatment choices for bacterial infections [20]. One of the most effective mechanisms of resistance to $\beta$-lactams is the production of $\beta$-lactamase enzymes such as ESBLs [21]. ESBLs were derived as a result of mutation in as few as one amino acid of their progenitors. This resulted in a profound change in enzyme activities of the ESBLs. The ESBLs are able to hydrolyze the third generation cephalospoms or aztreonam hence the extension of spectrum of activity when compared to the parent enzymes. Genes for ESBL enzymes are often carried on plasmids facilitating their rapid dissemination [22]. These genes also carry resistance to other antimicrobial agents [23].

A number of study describing the prevalence of ESBL-producing Enterobacteriaceae has increased rapidly worldwide [24]-[26]. A total of five (15.15\%) ESBL producers were detected in this study; 3 Escherichia coli, 2 Pseudomonas aeruginosa and 1 Klebsiella pneumoniae. Beta-lactamase gene has been amplified by PCR in waste water [3]. Though bacteria are essential in eliminating degradable substances from the environment, most hospital wastes are stable and non-biodegradable. The concentration of these wastes especially antibiotics maybe much higher if the active compound persist and accumulate. Broader spectrum of activity may also occur, which is usually the case with ESBLs. The organisms harboring ESBLs in this study were all pan drug resistance. This could pose a major risk to public health. The isolates in this study were all MDR and the water samples from which isolates were obtained did not undergo any form of treatment before they were poured into the environment. An important analogy observed in this study is a possibility of having a higher prevalence of ESBL producers in the hospital environment sampled because the waste waters from the hospitals were always carelessly thrown away by cleaners as they wash patient's bed covers, mob floor or carry out other activities involving water.

The current work also revealed that these organisms harbored plasmids, as shown by plasmid curing and plasmid extraction experiments. The fact that these organisms harbored plasmid is an indication that they can acquire new resistance genes through horizontal transfer [27]. High levels of multi and pan drug resistance was observed in isolates in this study. To minimize the spread of drug resistance from hospital to the environment, it 
is important to initiate and implements sustainable solid sewage treatment plants and to train hospital cleaners.

This result of this investigation also revealed transfer of resistance genes between ESBL producing isolate and non-ESBL producing isolates. The transfer as well as the emergence of new combination of resistance genes is favored in environment where bacteria aggregates are high. [28]. Aggregates of bacteria i.e. biofilms are very high in septic tanks. Important prerequisite that aid transfer is long exposure, high concentration of antibiotics and high bacteria density. The hospital environment or the septic tanks where the waste water are discharge without treatment meets these conditions and therefore favors the transfer of resistance. Huge public health implications results when such hospital septic tanks, collapse or pipes are broken and sewage leak into the environment. These organisms can be transferred to humans through several obvious means. Treatment with conventional antibiotics may become ineffective since these transferred organisms have become resistant to the commonly used drugs.

\section{Conclusion}

Isolates obtained from hospital waste water in this study were not only pan or multi drug resistant but also were ESBLs producers and harboured plasmids. Provision of means of treating hospital waste water before they are piped into septic tanks should be done. Educating hospital cleaners and care givers on the dangers of carelessly throwing away waste water should also be done. All these will help to create a save environment.

\section{References}

[1] Chitnis, V., Chitnis, D.O., Patil, S. and Ravi Kant, S. (2000) Hospital Effluent a Source of Multiple Drug Resistant Bacteria. Current Science, 79, 989-991.

[2] Chitnisa, V., Chitinisa, S., Vaidyaa, K., Ravikants, S., Patilb, S. and Chintinisa, D.S. (2004) Bacterial Population Changes in Hospital Effluent Treatment Plant in Central India. Water Research, 38, 441-447. http://dx.doi.org/10.1016/j.watres.2003.09.038

[3] Schwartz, T., Kohnen, W., Jansen, B. and Obst, U. (2003) Detection of Antibiotic-Resistant Bacteria and Their Resistance Genes in Waste Water, Surface Water and Drinking Waterbiofilms. FEMS Microbiology Ecology, 43, 325-335.

[4] Truong, P. (2000) Vetiver System for Water Quality Improvement. 3rd International Conference of Vetiver and Water, 61-72.

[5] Xia, H.P., Ke, H.H., Deng, Z.P., Tan, P. and Liu, S.Z. (2004) Ecological Effectiveness of Vetiver Constructed Wetlands in Treating Oil Refined Wastewater. 3rd International Conference of Vetiver and Water.

[6] Kummerer, K. (2004) Resistance in the Environment. Journal of Antimicrobial Chemotherapy, 54, 311-320. http://dx.doi.org/10.1093/jac/dkh325

[7] Harwood, V.J., Bronwell, M., Perusek, W. and Whitlock, J.E. (2001) Vancomycin-Resistant Enterococcus spp. Isolated from Wastewater and Chicken Feces in the United State. Applied and Environmental Microbiology, 67, 49304933. http://dx.doi.org/10.1128/AEM.67.10.4930-4933.2001

[8] Iversen, A., Franklin, A. and Kuhn, I. (2002) High Prevalence of Vacomycin-Resistant Enterococci in Swedish Sewage. Journal of Applied and Environmental Microbiology, 6, 2838-2842. http://dx.doi.org/10.1128/AEM.68.6.2838-2842.2002

[9] Blanch, A.R., Caplin, J.L., Iversen, A., Kuhn, I., Manero, A., Taylor, H.D. and Vilanpva, X. (2003) Comparison of Enterococcal Populations Related to Urban and Hospital Wastewater in Various Climatic and Geographic European Regions. Journal of Applied Microbiology, 51, 1285-1292.

[10] Clinical and Laboratory Standards Institute (2009) Percformance Standards for Antimicrobial Susceptibility Testing: Seventeenth Informational Supplement. CLSI Document M100-517. Clinical and Laboratory Standards Institute, Wayne.

[11] Mirmomeni, M.H., Colagar, A.H. and Ghazaey, S. (2007) Molecular Study of Salmonella enteritidis in Poultry Samples by Per, Plasmid Curing, Antibiotic Resistance and Protein Pattern Analysis. Pakistan Journal of Biological Sciences, 10, 1562-1570. http://dx.doi.org/10.3923/pjbs.2007.1562.1570

[12] Birnboim, H.C. and Doly, J. (2014) A Rapid Alkaline Extraction Procedure for Screening Recombinant Plasmid DNA. Nucleic Acids Research, 7, 1513-1523. http://dx.doi.org/10.1093/nar/7.6.1513

[13] Clinical and Laboratory Standards Institute. Performance Standards for Antimicrobial Susceptibility Testing: 20th Informational Supplement. CLSI Document VET01-A4 and VET01S-Ed3, CLSI, Wayne.

[14] Chen, L., Chen, Z.L., Lin, J.H., Zeng, Z.L., Ma, J.Y. and Jiang, H.X. (2007) Emergence of RmtB Methylase-Producing Escherichia coli and Enterobacter Cloacae Isolates from Pigs in China. Journal of Antimicrobial Chemotherapy, 59, 
880-885.

[15] Iroha Iroha, I.R., Amadi, E.S., Nwazo, A.C. and Ejike-Ugwu, P.C. (2010) Detection of Plasmid Borne ESBLs from Blood and Urine Isolates of Gram Negative Bacteria from University Teaching Hospital in Nigeria. Current Research in Bacteriology, 3, 77-83. http://dx.doi.org/10.3923/crb.2010.77.83

[16] Muela, A., Pocino, I. and Arana, J. (1994) Effects of Growth Phase and Parental Cell Survival in River Water on Plasmid Transfer between Escherichia coli Strains. Applied and Environmental Microbiology, 60, 4273-4278.

[17] Saini, S., Das, B.K., Kapil, A., Nagarajan, S.S. and Sarma, R.K. (2004) The Study of Bacterial Flora of Different Types in Hospital Waste: Evolution of Waste Treatment at AIIMS Hospital, New Delhi. The Southeast Asian Journal of Tropical Medicine and Public Health, 35, 986-989.

[18] Abdulaziz, Y.A. (2011) Review on Hospital Wastes and Its Possible Treatments. Egyptian Academic Journal of Biological Sciences, 3, 55-62.

[19] Horii, T., Arakawa, Y., Ohta, M., Ichiyama, S., Wacharotayankun, R. and Kato, N. (1993) Plasmid Mediated AmpCType $\beta$-Lactamase Isolated from Klebsiella pneumoniae Confers Resistance to Broad Spectrum $\beta$-Lactams Including Moxalactam. Antimicrobial Agents and Chemotherapy, 37, 984-990. http://dx.doi.org/10.1128/AAC.37.5.984

[20] Molstad, S., Lundborg, C.S. and Karlsson, A.K. (2002) Antibiotic Prescription Rates Vary Markedly between 13 European Countries. Scandinavian Journal of Infectious Diseases, 34, 366-371. http://dx.doi.org/10.1080/00365540110080034

[21] Davoud, K. and Shahla, M. (2011) Emergence of Multiple $\beta$-Lactamases Produced by Escherichia coli Clinical Isolates from Hospitalized Patient in Kerman, Iran. Jundishapur Journal of Microbiology, 3, 137-145.

[22] Jean, S.S., Teng, L.J., Hsueh, P.R., Ho, S.W. and Luh, K.T. (2002) Antimicrobial Susceptibility among Clinical Isolates of Extended-Spectrum Cephalosporin-Resistant Gram-Positive Bacteria in a Taiwanese University Hospital. Journal of Antimicrobial Chemotherapy, 49, 69-76. http://dx.doi.org/10.1093/jac/49.1.69

[23] Rawat, D. and Nair, D. (2010) Extended-Spectrum $\beta$-Lactamases in Gram Negative Bacteria. Journal of Global Infectious Diseases, 2, 263-274.

[24] Singhal, S., Mathur, T., Khan, S., Upadhyay, D.J., Chugh, S., Gaind, R. and Rattan, A. (2005) Evaluation of Methods for AmpC Beta-Lactamase in Gram Negative Clinical Isolates from Tertiary Care Hospitals. Indian Journal of Medical Microbiology, 23, 120-124. http://dx.doi.org/10.4103/0255-0857.16053

[25] Reich, F., Atanassova, V., \& Gunter, K. (2013) Extended-Spectrum $\beta$-Lactamase and AmpC-Producing Enterobacteria in Healthy Broiler Chickens, Germany. Emerging Infectious Disease, 19, 1253-1258. http://dx.doi.org/10.3201/eid1908.120879

[26] Yusuf, I., Yusha’u, M., Getso, M., Yahaya, H., Bala, J., Aliyu, I. and Haruna, M. (2012) Detection of Metallo-BetaLactamases among Gram Negative Bacterial Isolates from Murtala Muhammed Specialist Hospital, Kano and Almadina Hospital Kaduna, Nigeria. Bayero Journal of Pure and Applied Sciences, 5, 84-88.

[27] Bunny, K.L., Hall, R.M. and Stokes, H.W. (1995) New Mobile Gene Cassettes Containing an Aminoglycoside Resistance Gene, aacA7, and a chloramphenicol Resistance Gene, catB3, in an Integron in pBWH301. Antimicrobial Agents and Chemotherapy, 39, 686-693. http://dx.doi.org/10.1128/AAC.39.3.686

[28] Murray, B.E. (1997) Antibiotic Resistance. Journal of Advances in Internal Medicine, 42, 339-367.

\section{Submit or recommend next manuscript to SCIRP and we will provide best service for you:}

Accepting pre-submission inquiries through Email, Facebook, Linkedin, Twitter, etc

A wide selection of journals (inclusive of 9 subjects, more than 200 journals)

Providing a 24-hour high-quality service

User-friendly online submission system

Fair and swift peer-review system

Efficient typesetting and proofreading procedure

Display of the result of downloads and visits, as well as the number of cited articles

Maximum dissemination of your research work

Submit your manuscript at: http://papersubmission.scirp.org/ 